\title{
An integrated multiple layer perceptron-genetic algorithm decision support system for photovoltaic power plant site selection
}

\author{
Rajkumari Malemnganbi, Benjamin A. Shimray
}

Department of Electrical Engineering, National Institute of Technology Manipur, Manipur, India

\begin{tabular}{l} 
Article Info \\
\hline Article history: \\
Received Mar 23, 2021 \\
Revised Aug 6, 2021 \\
Accepted Sep 1, 2021 \\
\hline
\end{tabular}

Keywords:

Analytical hierarchy process Back propagation

Multi-criteria decision making

Multiple layer perceptron

Site selection

Solar power plant

\begin{abstract}
There is a need for non-renewable energy sources in generation of power for almost every domestic and commercial purposes. This source of energy helps in the development of a country. Because of the increasing usage of the fossil fuels and depletion of these resources, our focus has been shifted towards the renewable sources of energy like solar, water and wind. Therefore, in the present scenario, the usage of renewable sources has been increasing rapidly. Selection of a solar power plant (SPP) requires environmental factor, local terrain, and local weather issues. Thus, a large amount of investment is required for installation. Multi-criteria decision making (MCDM) is a method that identifies one in choosing the best sites among the other proposed options. This paper gives a detailed study of optimal ranking of SPP site using analytical hierarchy process (AHP), multiple layer perceptron (MLP) neural network trained with back propagation (BP) algorithm and genetic algorithm (GA). Three SPP sites of India were considered and various important criteria like local weather, geographical location, and environmental factors are included in our study as SPP site selection is a multi-criteria problem. A precise comparison of these three methods is listed in this paper.
\end{abstract}

This is an open access article under the CC BY-SA license.

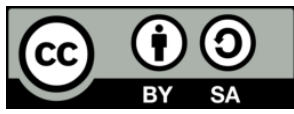

\section{Corresponding Author:}

Rajkumari Malemnganbi

Department of Electrical Engineering, National Institute of Technology Manipur

Langol Rd, Lamphelpat, Imphal, Manipur 795004, India

Email: rkmalemdevi@gmail.com

\section{INTRODUCTION}

Energy is an essential part in our daily life. Human population is estimated to rise from 6.9 billion to 13.1 billion by the end of this century [1]. As a result, the consumption of energy is increase with the increase in population. Michael [2] reported that the demand in global energy is likely to be doubled in the $21 \mathrm{st}$ century. Thus, energy needs have become a very important international and national agenda. Fossil fuels are formed naturally and take a long time to form and their price increases as its reserves decreases. The burning of fossil fuels also severely degrades the environment; on the contrary, renewable energy sources are unlimited as they are replenished constantly in nature.

To compensate for the ever-growing demands, most of the countries have started using renewable energy sources for generation of power. Such sources of energy depend on social factor and environmental issues. Solar power plant (SPP) is a popular renewable source and are widely used across the globe. Investors have shown immense interest in solar power project because of its availability, pollution free environment, low maintenance and operating cost. This have enhance the solar power project to progress rapidly [3]. 
The multi-criteria evaluation (MCE) approach has been an important tool to assist decision-makers in sustainable energy planning. According to Rosen et al. [4], MCE helps in evaluating the performance criteria of the project. Haidipour et al. [5], identified areas for suitable shrimp aquaculture development using geographical information system (GIS), analytical hierarchy process (AHP), and MCE in the coastal region of Iran, Latinopoulos, and Keechagia. Shamboo et al. [6] demonstrated various soft computing methods to prioritize the sites of SPP in India. Malemnganbi and Shimray [7] presented a detailed review on site selection of solar power plant quoting various power plants and the methods used to rank the plants. SPP site selection techniques based on data envelope analysis (DEA) were proposed by Thongpun [8], in their work and criteria like temperature, land availability, and land cost were taken into consideration. A hybrid neuro-fuzzy decision support system [9] and multiple layer perceptron-genetic algorithm (MLP-GA) based decision support system were proposed and implemented for large hydro power plant selection. Ching-Ter also proposes am multi-choice goal programming model to deal with capacity expansion planning problem of the renewable energy industry [10].

Rapal et al. [11] benefits AHP to assessed potential sites for wind and solar deployment project. In this paper, experts' opinions were evaluated to prioritize the scores. Four regions of Philippines were considered for the case study. Further it has also shown that solar/wind intensity is the most important consideration for selecting the site. In another paper authored by Tunc et al. [12], AHP has been analyzed for weighing the criteria and the weights were compared to the survey results, Analysis being performed using GIS software. Colak et al. [13], have done a case study for Malatya, Turkey using GIS and AHP for utility scale SPP. Fang et al. [14], also proposed technique for order preference by similarity to ideal solution (TOPSIS) and to select the proper sites of SPP. Garni and Awasthi [15] also portrayed GIS-AHP for site selection in Saudi Arabia. Akkas et al. [16] compared various methods that helps in prioritizing the SPP sites in Turkey. Evaluation of environmental and solar radiation characteristics is required that affects the technical performance. [17]. Rao and Lakshmi recently developed a new multi-attribute decision-making (MADM) method, named "R-method". This method is very simple, effective, and can be used to deal with any number of alternatives and attributes. The method is competitive to other well-known MADM methods and can be easily used to find the best alternative from among the available alternatives [18], [19].

\section{CASE STUDY}

The sites that have been considered in our study are those that are approved under the solar park scheme of ministry of new and renewable energy (MNRE). Solar radiation, Temperature, humidity, precipitation for these sites, have been collected. Distance to national highway $(\mathrm{NH})$, coastal area and reserved area for the proposed site are referred [20]. The important criteria and sub criteria that are used in our present studies are explained in below:

a. Temperature

The PV modules' efficiencies decrease as temperature rises. In general, the PV modules' characteristics were determined at standard temperature $25 \mathrm{C}$. For every rise in temperature $\left({ }^{\circ} \mathrm{C}\right)$, the efficiency of silicon modules gets reduced by $0.5 \%$.

b. Distance from the national highway

SPP should be located in the area which is easily accessible [21]. Nearness to the national highway is considered as an important criterion. This will help in reducing the cost of equipment loading and transportation.

c. Solar resources

Annual solar irradiation received in the proposed location is an important criterion for optimal site selection of SPP. diffuse horizontal irradiation (DHI), direct normal irradiance (DNI) and global horizontal irradiance (GHI), describes the solar resources of any location. Higher the energy resources, higher will be the energy yield.

d. Distance from the protected area

A large SPP requires a large area to be cleared which may negatively affect ecological balance and result in loss of important and endangered species of plant and animal. Human activities have lots of chances to affect protected areas [21]. Therefore, before installing SSP, distance from the protected area must be considered.

e. Sunshine hour

Sunshine hour, one of the most important factors, signifies the amount of solar radiation reaching the earth's surface. Khan and Rathi [22] acknowledge that there are 250 to 300 clear sunny days in India in a year. f. Wind speed

The mounting structure of SPP must withstand a wind speed of $150 \mathrm{~km} / \mathrm{hr}$. The area with heavy wind speed should be avoided as it may affect the tracking system. 
g. Seismic zone

h. Humidity

High-risk Seismic zone areas are not recommended for setting up large SPP.

Approximately $30 \%$ of the solar energy was either absorbed or reflected by the ocean, clouds, and landmass. Loss in solar energy occurs due to the reflection/absorption of solar energy by landmass, oceans, and clouds. There will be an increase in the efficiency of the solar cell if the humidity decreases and vice versa.

i. Distance to coastland

The salt level in the atmosphere may also lead to the acceleration of corrosions and the distance to SPP sites to sea should be considered as important criteria.

\section{PROPOSED METHOD}

\subsection{Analytical hierarchy process (AHP)}

It is a process that is based on expert's opinions and measures the expert scale and acquire the priorities with the help of a binary comparisons [23]. Designing the decision hierarchy is the first step in the process of AHP. The weights of the criteria, sub-criteria calculated using AHP is given in Table 1. The last step is to prioritize the three SPP sites using the values obtained from the case study. The priorities weights are given in Table 1.

Table 1. Weights calculated

\begin{tabular}{cccccc}
\hline Criteria & \multicolumn{2}{c}{ Sub Criteria } & Pavagada Solar Park & Bhandla Solar Park & West Bengal Solar Park \\
\hline Climate & GHI & 0.215928 & 0.215928 & 0.210961 & 0.19643 \\
0.531163 & DHI & 0.215928 & 0.215928 & 0.188094 & 0.189606 \\
& DNI & 0.215928 & 0.193946 & 0.215928 & 0.197682 \\
& Temperature & 0.082454 & 0.080698 & 0.075693 & 0.082455 \\
& Sunshine Hour & 0.162751 & 0.161840 & 0.162491 & 0.162752 \\
& Wind Speed & 0.050228 & 0.050228 & 0.042553 & 0.043865 \\
& Precipitation & 0.028390 & 0.009746 & 0.028390 & 0.019192 \\
Geography & Humidity & 0.028390 & 0.016735 & 0.055667 & 0.045543 \\
Transportation & Seismic Belt & 0.058254 & 0.058254 & 0.221431 & 0.094434 \\
& Distance from & 0.285380 & 0.285386 & & 0.125196 \\
Environment & National & & & & 0.003994 \\
Overall Priority & Highway & & & & 1.039075 \\
\end{tabular}

\subsection{MLP-BP}

Multiple layer perceptron (MLP) uses a supervised network configuring various layers of neurons. It comprises of three layers viz. input layer, the hidden layer which is considered as the brain of the network, and an output layer as shown in Figure 1 . The $i^{\text {th }}$ layer of each neuron is connected to (i+1) ${ }^{\text {th }}$ layer of all neurons. This connection weight has to be determined by using a training algorithm known as back propagation [24].

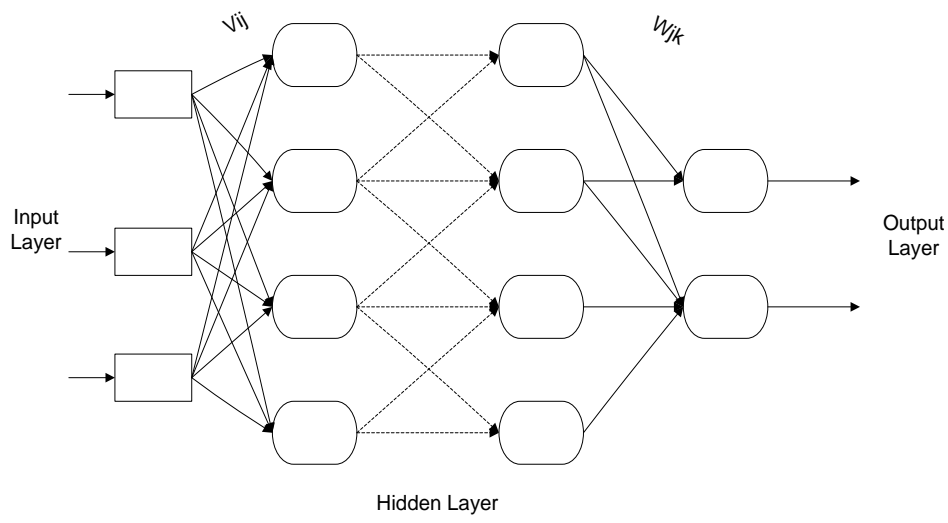

Figure 1. MLP architecture 


\subsection{Multiple layer perceptron-genetic algorithm (MLP-GA)}

In multilayer perceptron with a genetic algorithm (MLP-GA), the neural network is trained by using genetic algorithm to find the correct connection weights [25]. Here back propagation is replaced by GA to overcome the unfitting selection of the starting weights as improper initial weights can cause delay in convergence. While GA, executes a comprehensive search, and has less chance of getting caught in local minima. The various steps of MLP-GA are explained in the section 3.3.1 to 3.3.6.

\subsubsection{Weight initialization}

To advance MLP, the GA genotype is defined as the weight list. The weights are characterized by a binary number. Every solution is a bit string and it signifies the connection weights of the neural network layers.

$$
T W=(I * H N+H N * O N)
$$

Where $\mathrm{TW}=$ no of total weights, I=input pattern size, $\mathrm{HN}=$ no. of hidden neurons, $\mathrm{ON}=$ no. of output neurons. In our study, $\mathrm{I}=13, \mathrm{HN}=3, \mathrm{ON}=2$ Thus, $\mathrm{TW}=45$. Now

$$
G L=[B(I * H N+H N * O N)]
$$

where, GL=gene length, $\mathrm{B}=$ No of bits/weight. In our study $\mathrm{B}=16$ (16 bit binary number). Hence, GL=720.

\subsubsection{Reconstructing phenotype from the genotype}

If we consider

$$
\mathrm{y}_{\mathrm{m}}=\sum_{\mathrm{k}=1}^{\mathrm{B}} \mathrm{b}_{\mathrm{mk}} 2^{-\mathrm{k}}
$$

where, $b_{\mathrm{mk}}=\mathrm{k}_{\mathrm{th}}$ bit from $\mathrm{m}_{\mathrm{th}}$ weight. Then

$$
\mathrm{w}_{\mathrm{m}}=\mathrm{y}_{\mathrm{m}} * \mathrm{~A}+\mathrm{B}
$$

where, $\mathrm{w}_{\mathrm{m}}=$ weight in the string or solution, $\mathrm{A}=$ scaling factor, $\mathrm{B}=$ shifting factor. In our work $\mathrm{A}=20, \mathrm{~B}=-10$, for the weights to take value from $[-10,10]$. Thus, we can calculate the weights $v_{j m}$ and the weight $w_{k j}$. Where, $v_{j m}=$ Weight from the $m^{t h}$ input to the $j^{\text {th }}$ hidden neutron, $w_{k j}=$ Weight from the $j^{\text {th }}$ hidden neuron to the $k^{\text {th }}$ output neuron.

\subsubsection{Hidden layer and the output layer output}

To calculate the output of the hidden neurons, the (5) and (6) are used:

$$
\begin{aligned}
& \mathrm{S}_{1}=\sum_{\mathrm{m}, \mathrm{j}} \mathrm{v}_{\mathrm{jm}} * \mathrm{x}_{\mathrm{pm}} \\
& \mathrm{y}_{\mathrm{j}}=\operatorname{sigmoid}\left(\mathrm{S}_{1}\right)
\end{aligned}
$$

where sigmoid=unipolar activation function, $y_{j}=$ the output of the $j^{\text {th }}$ hidden neuron. To calculate the output of the output neurons:

$$
\begin{aligned}
& \mathrm{S}_{2}=\sum_{\mathrm{j}, \mathrm{k}} \mathrm{w}_{\mathrm{kj}} * \mathrm{y}_{\mathrm{j}} \\
& \mathrm{o}_{\mathrm{k}}=\operatorname{sigmoid}\left(\mathrm{S}_{2}\right)
\end{aligned}
$$

where $o_{k}=$ output of the $k^{\text {th }}$ output neuron. For all the input patterns, (7) and (8) is implemented to find the output. The (9) is used to update the error,

$$
E=\frac{1}{2} \sum_{k=0}^{k}\left(d_{k}-o_{k}\right)^{2}
$$


where $\mathrm{d}_{\mathrm{k}}=$ desired output. All these steps are executed for all the training samples.

\subsubsection{Fitness of the string or solution}

To calculate the fitness of the string or solution (10) is carried out,

$$
\text { fitness }=\frac{1-\mathrm{E}}{\mathrm{N}}
$$

where $\mathrm{N}=$ no. of patterns or training samples. The steps from 3.3.2 are repeated for every string or solution of the population.

\subsubsection{Selection}

In the selection process, the solution or string that has the maximum fitness value is determined. The operation will terminate only when maximum fitness value is larger than the desired fitness value. For the testing phase, the weight associated with maximum fitness value string or solution is used.

\subsubsection{Reproduction}

Mutation and Crossover are used to modify the population. Until we obtain a string or solution having the fitness value larger than the desired fitness value, the steps from 3.3.2 are repeated.

\section{IMPLEMENTATION}

This section illustrates the result attained after applying AHP, MLP-BP and MLP-GA. For training the neural network using the proposed algorithm the selected sub-criterion is classified into different class as poor, average, and good as shown in Table 2. The numeric data for the solar power plants used in this paper is given in Table 3. Our work consists of 12 input, 3 hidden neurons, and 2 output neurons. The desired output is set as $(0,0)$ for poor $(0,1)$ for average, $(1,0)$ for good. We run the algorithm for different numbers of training cycles starting from 1,000 cycles to 10,000 cycles.

Table 2. Selected criteria

\begin{tabular}{|c|c|c|c|c|}
\hline Criteria & Sub-Criteria & Class good & Class Average & Class Poor \\
\hline \multirow[t]{6}{*}{ Climate } & Global Horizontal Irradiation (GHI) & $5.7 \leq$ & $4.5-4.99$ & $0.01-4.49$ \\
\hline & Direct Horizontal Irradiation (DHI) & $1.8-3$ & $1.5-1.79$ & $0.01-1.49$ \\
\hline & Direct Normal Irradiation (DNI) & $5.7-7$ & $5-5.69$ & $0.01-4.99$ \\
\hline & Sunshine Hour & $13.01-24$ & $12-13$ & $0.01-11.99$ \\
\hline & Wind Speed & $0.01-9$ & $9.01-20$ & $20.01-100$ \\
\hline & Precipitation & $0.01-40$ & $40.01-100$ & $100.01-300$ \\
\hline Transportation & Distance from National Highway & $0.01-9.99$ & $10-30$ & $30.01-200$ \\
\hline \multirow[t]{2}{*}{ Environment } & Distance from protected area & $50.01-200$ & $20-50$ & $0.01-19.99$ \\
\hline & Distance from coastal area & $500.01-1500$ & $50.01-500$ & $0.01-50$ \\
\hline
\end{tabular}

\subsection{MLP-BP and MLP-GA comparison}

MLP trained with BP and MLP trained with GA are compared in this section for various training cycles. The results obtained using the MLP-GA algorithm are given in Table 3. Figure 2 shows a better analysis for different iterations. The comparison in Tables 4 and 5 show that MLP-GA achieves better results than MLP-BP algorithm and AHP. Also, with lesser number of iterations, MLP-GA can precisely rank the power plant sites. Figure 2 shows the classification rate graph of MLP-BP and MLP-GA for 1000, 5000, 10000, 30000, 60000, 80000 and 100000 iterations.

Similarly, it is shown that the classification rate for MLP-GA has achieved a $100 \%$ success rate starting from 5000 learning cycles which means, it can accurately rank the given solar plant installations. On the other hand, the classification rate is only $75 \%$ at 30000 to 1lakh iterations. Therefore, it can be concluded that that MLP neural network trained by GA shows much better efficiency in accurately classifying and identifying potential sites for the installation of solar power plants. In our quest for reasonable and acceptable solution for optimal site selection of SPP, we explore two soft computing technique viz.-MLP-BP, MLP-GA and a MCDM technique AHP. A comparison of these three techniques is presented in Table 5. Thus, from this table, we can conclude that Bhandla SPP in Rajasthan, being the highest estimated solar energy potential in India, is the most suitable site for SPP followed by Pavagada SPP in Karnataka and West Bengal SPP. 
Table 3. MLP-GA results

\begin{tabular}{|c|c|c|c|c|}
\hline Power Plant Site & $\begin{array}{c}\text { Test input }\left(\mathrm{x}_{\mathrm{pm}}\right) \\
\text { (The } 12 \text { attributes in each plant) }\end{array}$ & $\begin{array}{c}\text { Output from hidden layer } \\
Y_{\mathrm{j}}=\operatorname{sigmoid}\left(\mathrm{s}_{1}\right) \\
\text { Where } \mathrm{s}_{1}=\mathrm{v}_{\mathrm{pm}}{ }^{*} \mathrm{x}_{\mathrm{pm}}\end{array}$ & $\begin{array}{c}\text { Output from output } \\
\text { layer } \\
\begin{array}{c}\mathrm{O}_{\mathrm{k}}=\operatorname{sigmoid}\left(\mathrm{s}_{2}\right) \\
\text { where } \\
\mathrm{S}_{2}=\mathrm{w}_{\mathrm{kj}} * \mathrm{x}_{\mathrm{pm}}\end{array}\end{array}$ & Rank \\
\hline Pavagada SPP, & $5.32,1.94,5.21,24.05,12.5,9.1,89.63,8$ & $\mathrm{Y}[0]=1.000000$ & $0.000000,0.992683$ & II \\
\hline Karnataka & $7.83,4.3,22.5,88.5,379,-1$ & $\mathrm{Y}[1]=1.000000$ & & \\
\hline Bhandla SPP, Rajasthan & $\begin{array}{c}5.2,1.69,5.8,25.64,12.55,10.74,30.77 \\
51.83,4.5,29,146,752,-1\end{array}$ & $\begin{array}{l}Y[0]=1.00000 \\
Y[1]=0.000000\end{array}$ & $1.000000,0.000000$ & I \\
\hline West Bengal solar park & $\begin{array}{c}4.84,1.73,5.31,23.58,12.57,10.42,267 . \\
5,76.67,5.5,6.8,186,2.4,-1\end{array}$ & $\begin{array}{l}\mathrm{Y}[0]=0.000000 \\
\mathrm{Y}[1]=1.000000\end{array}$ & $0.000000,0.000000$ & III \\
\hline
\end{tabular}

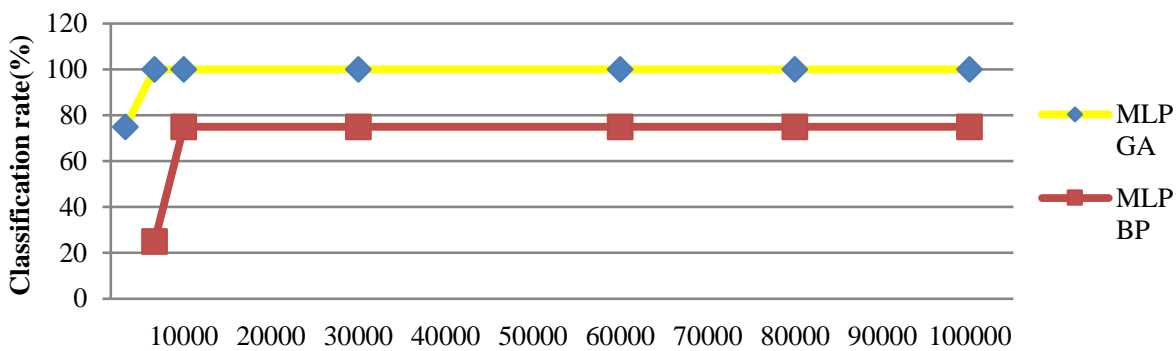

Training cycles

Figure 2. Classification rate graph

Table 4. Results comparing for 5000 and 10000 training cycles

\begin{tabular}{|c|c|c|c|c|c|c|}
\hline Sl. no & Power Plant & $\begin{array}{l}\text { No. of } \\
\text { iteration }\end{array}$ & $\begin{array}{c}\text { MLP-BP } \\
\text { The output from the output } \\
\text { layer }\end{array}$ & Rank & $\begin{array}{l}\text { MLP-GA } \\
\text { The output from } \\
\text { the output layer }\end{array}$ & Rank \\
\hline 1 & Pavagada SPP & 5000 & $0.484145,0.515413$ & I & $\begin{array}{c}0.000000 \\
1.000000\end{array}$ & II \\
\hline 2 & Bhandla SPP & 5000 & $0.484145,0.515413$ & I & $\begin{array}{l}1.000000 \\
0.000000\end{array}$ & I \\
\hline 3 & $\begin{array}{l}\text { West Bengal } \\
\text { Solar Park }\end{array}$ & 5000 & $0.484145,0.515413$ & I & $\begin{array}{c}0.000000 \\
1.000000\end{array}$ & II \\
\hline 1 & Pavagada SPP & 10000 & $0.484256,0.515524$ & I & $\begin{array}{l}0.000000 \\
0.992683\end{array}$ & II \\
\hline 2 & Bhandla SPP & 10000 & $0.484256,0.515524$ & I & $\begin{array}{l}1.000000 \\
0.000040\end{array}$ & I \\
\hline 3 & $\begin{array}{l}\text { West Bengal } \\
\text { Solar Park }\end{array}$ & 10000 & $0.007202,0.007228$ & II & $\begin{array}{l}0.000000 \\
0.000000\end{array}$ & III \\
\hline
\end{tabular}

Table 5. Result for MLP-BP application

\begin{tabular}{|c|c|c|c|c|c|c|c|}
\hline $\begin{array}{l}\text { S1. } \\
\text { no }\end{array}$ & Power Plant & $\begin{array}{l}\text { MLP-BP } \\
\text { The output from the } \\
\text { output layer }\end{array}$ & Rank & $\begin{array}{c}\text { AHP } \\
\text { Priorities }\end{array}$ & Ranking & $\begin{array}{l}\text { MLP-GA } \\
\text { The output } \\
\text { from the } \\
\text { output layer }\end{array}$ & Ranking \\
\hline 1 & $\begin{array}{l}\text { Pavagada } \\
\text { SPP }\end{array}$ & $0.484256,0.515524$ & I & 1.351796502 & I & $\begin{array}{c}0.000000 \\
0.992683\end{array}$ & II \\
\hline 2 & $\begin{array}{c}\text { Bhandla } \\
\text { SPP }\end{array}$ & $0.484256,0.515524$ & I & 1.354799024 & I & $\begin{array}{l}1.000000 \\
0.000040\end{array}$ & I \\
\hline 3 & $\begin{array}{c}\text { West Bengal } \\
\text { Solar Park }\end{array}$ & $0.007202,0.007228$ & II & 1.039075495 & II & $\begin{array}{c}0.000000 \\
0.000000\end{array}$ & III \\
\hline
\end{tabular}

\section{CONCLUSION}

The investigation process for installing a SPP mounting structure involves the participation of different stakeholders which even include a common man. Unmistakably identifying suitable sites for the 
solar plant helps in saving time and money of the decision-makers and also promotes future infrastructure developments. Also integrating related factors into the decision making process will provide an improved results and the make the site selection technically and economically achievable. Various decision-makers 'shots to rap power without bearing in mind the unpleasant effect which may, in turn, be a threat to human existence. In our present work, a detail analysis to assist decision making body is taken up using two robust soft computing techniques. The methodology applied can accurately rank the probable sites for solar power plant installation. A certain set of quantitative and qualitative factors may also be required in site selection problem. There is also a requirement for linguistic information. Thus, application of fuzzy logic can be of great help to address multi criteria site selection problem such as power plant sites and will be the future research work related to our present study.

\section{REFERENCES}

[1] D. Hoornweg and K. Pope, "Population predictions for the world's largest cities in the 21st century," Environment and Urbanization, vol. 29, no. 1, pp. 195-216, Apr. 2017, doi: 10.1177/0956247816663557.

[2] J. Micael, A. C. Costa, P. Aguiar, A. Medeiros, and H. Calado, "Geographic information system in a multi-criteria tool for mariculture site selection," Coastal Management, vol. 43, no. 1, pp. 52-66, Jan. 2015, doi: 10.1080/08920753.2014.985178.

[3] E. Borgogno Mondino, E. Fabrizio, and R. Chiabrando, "Site selection of large ground-mounted photovoltaic plants: a GIS decision support system and an application to Italy," International Journal of Green Energy, vol. 12, no. 5, pp. 515-525, May 2015, doi: 10.1080/15435075.2013.858047.

[4] L. Rosén et al., "SCORE: A novel multi-criteria decision analysis approach to assessing the sustainability of contaminated land remediation," Science of The Total Environment, vol. 511, pp. 621-638, Apr. 2015, doi: 10.1016/j.scitotenv.2014.12.058.

[5] A. Hadipour, F. Vafaie, and V. Hadipour, "Land suitability evaluation for brackish water aquaculture development in coastal area of Hormozgan, Iran," Aquaculture International, vol. 23, no. 1, pp. 329-343, Feb. 2015, doi: 10.1007/s10499-014-9818-y.

[6] K. Sambhoo, S. Kadam, and A. Deshpande, "Ranking of sites for power plant installation using soft computing techniques-A thought beyond EIA," Applied Soft Computing, vol. 23, pp. 556-566, Oct. 2014, doi: 10.1016/j.asoc.2014.05.016.

[7] R. Malemnganbi and B. A. Shimray, "Solar power plant site selection: a systematic literature review on MCDM techniques used," in Electronic Systems and Intelligent Computing, Springer Singapore, 2020, pp. 37-48.

[8] A. Thongpun, S. Nasomwart, P. Peesiri, and N. Nananukul, "Decision support model for solar plant site selection," in 2017 IEEE International Conference on Smart Grid and Smart Cities (ICSGSC), Jul. 2017, pp. 50-54, doi: 10.1109/ICSGSC.2017.8038548.

[9] B. A. Shimray, K. M. Singh, T. Khelchandra, and R. K. Mehta, "A new MLP-GA-fuzzy decision support system for hydro power plant site selection," Arabian Journal for Science and Engineering, vol. 43, no. 12, pp. 6823-6835, Dec. 2018, doi: 10.1007/s13369-017-2885-4

[10] C.-T. Chang, "Multi-choice goal programming model for the optimal location of renewable energy facilities," Renewable and Sustainable Energy Reviews, vol. 41, pp. 379-389, Jan. 2015, doi: 10.1016/j.rser.2014.08.055.

[11] B. K. A. L. Rapal, A. K. R. Sumabat, and N. S. A. Lopez, "Analytical hierarchy process for multi- criteria site selection of utility scale solar and wind projects," The Italian Association of Chemical Engineering, vol. 61, pp. 1255-1260, 2017, doi: 10.3303/CET1761207

[12] A. Tunc, G. Tuncay, Z. Alacakanat, and F. S. Sevimli, "GIS based solar power plants site selection using analytic hierarchy process (AHP) in Istanbul, Turkey," The International Archives of the Photogrammetry, Remote Sensing and Spatial Information Sciences, vol. XLII-2/W13, pp. 1353-1360, Jun. 2019, doi: 10.5194/isprs-archives-XLII-2-W13-1353-2019.

[13] H. E. Colak, T. Memisoglu, and Y. Gercek, "Optimal site selection for solar photovoltaic (PV) power plants using GIS and AHP: A case study of Malatya Province, Turkey," Renewable Energy, vol. 149, pp. 565-576, Apr. 2020, doi: 10.1016/j.renene.2019.12.078.

[14] H. Fang, J. Li, and W. Song, "Sustainable site selection for photovoltaic power plant: An integrated approach based on prospect theory," Energy Conversion and Management, vol. 174, pp. 755-768, Oct. 2018, doi: 10.1016/j.enconman.2018.08.092.

[15] H. Z. Al Garni and A. Awasthi, "Solar PV power plant site selection using a GIS-AHP based approach with application in Saudi Arabia," Applied Energy, vol. 206, pp. 1225-1240, Nov. 2017, doi: 10.1016/j.apenergy.2017.10.024.

[16] O. P. Akkas, M. Y. Erten, E. Cam, and N. Inanc, "Optimal site selection for a solar power plant in the central anatolian region of Turkey," International Journal of Photoenergy, vol. 2017, pp. 1-13, 2017, doi: 10.1155/2017/7452715.

[17] D. T. Larose, Data mining methods and models. General and Introductory Computer Science, 2006.

[18] R. V. Rao and R. J. Lakshmi, "Ranking of Pareto-optimal solutions and selecting the best solution in multi- and many-objective optimization problems using R-method," Soft Computing Letters, vol. 3, p. 100015, Dec. 2021, doi: 10.1016/j.socl.2021.100015.

[19] R. V. Rao and J. Lakshmi, "R-method: A simple ranking method for multi-attribute decision-making in the industrial environment," Journal of Project Management, pp. 223-230, 2021, doi: 10.5267/j.jpm.2021.5.001.

[20] R. Malemnganbi and B. A. Shimray, "A comprehensive multi criteria model to rank solar power plant sites using soft computing techniques," Design Engineering, vol. 2021, no. 7, pp. 884-896, 2021.

[21] H. Yousefi, H. Hafeznia, and A. Yousefi-Sahzabi, "Spatial site selection for solar power plants using a GIS-based boolean-fuzzy logic model: a case study of Markazi Province, Iran,” Energies, vol. 11, no. 7, p. 1648, Jun. 2018, doi: 10.3390/en11071648.

[22] G. Khan and S. Rathi, "Optimal site selection of solar PV power plant in an Indian state using geographical information system (GIS)," International Journal of Emerging Research and Technology, vol. 2, pp. 260-266, 2014.

[23] T. L. Saaty, "Decision making with the analytic hierarchy process," International Journal of Services Sciences, vol. 1, no. 1, p. 83, 2008, doi: 10.1504/IJSSCI.2008.017590

[24] B. A. Shimray, K. M. Singh, T. Khelchandra, and R. . Mehta, "Optimal ranking of hydro power plant sites based on MLP-BP and fuzzy inference approach," in 2017 8th Annual Industrial Automation and Electromechanical Engineering Conference (IEMECON), Aug. 2017, pp. 189-193, doi: 10.1109/IEMECON.2017.8079586.

[25] B. A. Shimray, K. M. Singh, T. Khelchandra, and R. K. Mehta, "Ranking of sites for installation of hydropower plant using MLP neural network trained with GA: A MADM approach," Computational Intelligence and Neuroscience, vol. 2017, pp. 1-8, 2017, doi: $10.1155 / 2017 / 4152140$. 


\section{BIOGRAPHIES OF AUTHORS}
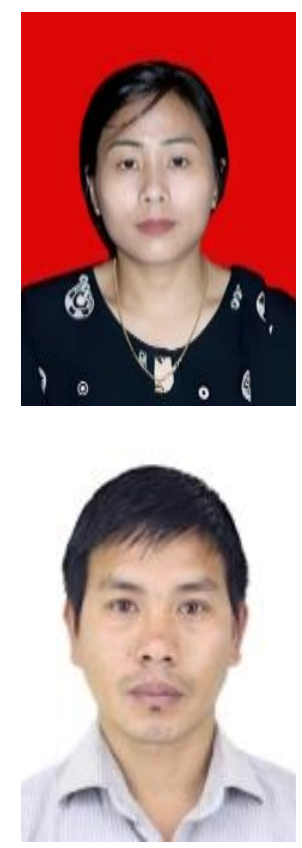

Rajkumari Malemnganbi (D) SC P completed B.E. in Electrical and Electronics Engineering and M. Tech in Power Electronics and Drives and started her teaching carrier from 2014. She is currently working as a Lecturer in EE dept. of National Institute of Technology Manipur, Imphal, India and also pursuing PhD. in the dept. of EE of NIT Manipur. Her area of interest is Drives and Renewable Energy. She can be contacted at email: rkmalemdevi@gmail.com.

Benjamin A Shimray (iD $8 \mathrm{SC}$ P received his Ph.D. and M. Tech from the National Institute of Technology Manipur (2018), Imphal and The National Institute of Engineering, Mysore (2010) respectively. Since 2011 he has been working as faculty member of department of Electrical Engineering, National Institute of Technology Manipur. His area of interest is application of Soft Computing techniques to renewable energy planning and management. He can be contacted at email: benjaminshimray@gmail.com. 